\title{
Sanksi Hukum terhadap Pelaku Tindak Pidana Korupsi Berdasarkan Hukum Positif dan Hukum Islam
}

\author{
Rahmayanti \\ Universitas Prima Indonesia \\ rahmayanti888@yahoo.com
}

\begin{abstract}
A B S T R A K
Undang-Undang tentang Pemberantasan Tindak Pidana Korupsi hanya diatur tentang korupsi material dan keuangan. Pasal 2 UU No. 31 Tahun 1999 yang disempurnakan dengan Undang-Undang No. 20 Tahun 2001 terhadap pelaku tindak pidana korupsi bagi penyelenggara negara dalam perspektif hukum Islam dilaksanakan karena sesuai dan sejalan dengan maqasid al-tasyri' dalam artian tetap mempertimbangkan kepentingan umum yang berorientasi pada kemaslahatan dan menolak segala kemungkaran. Oleh karena itu, yang menjadi pokok masalah dalam penelitian ini adalah sanksi hukum terhadap pelaku tindak pidana korupsi menurut hukum positif di Indonesia dalam hukum. Teori hukum pidana Islam yaitu mengenai pembagian dan operasionalisasi jinayah atau jarimah serta penerapan sanksi-sanksinya. Untuk memberantas korupsi ada empat usaha yang harus segera dilakukan, yaitu: pertama, Memaksimalkan hukuman. Hukuman dalam bentuk fisik perlu diwacanakan dan kalau bisa diterapkan bahkan kalau perlu sampai hukuman mati. Kedua, Penegakan Supremasi Hukum. Hukum harus tegak dan diberlakukan adil tanpa pandang bulu termasuk kalaupun korupsi dilakukan oleh para pejabat tinggi yang memiliki power dan pengaruh yang kuat. Ketiga, Perubahan dan perbaikan sistem. Metode penelitian yang digunakan adalah pendekatan normatif. Hasil penelitian menyimpulkan, korupsi pada umumnya dilakukan oleh orang yang memiliki kekuasaan dalam suatu jabatan sehingga karakteristik kejahatan korupsi selalu berkaitan dengan penyalahgunaan kekuasaan, dalam perspektif kejahatan yang terorganisir.
\end{abstract}

\section{Kata Kunci : Hukum Islam, Tindak Pidana Korupsi, Hukum Pidana Islam}

\section{ABSTRACT}

The Law on Corruption Eradication is only regulated on material and financial corruption. Article 2 of Law no. 31 of 1999 which is enhanced by Law no. 20 of 2001 against the perpetrators of corruption for the state administrators in the perspective of Islamic law is implemented because it corresponds and in line with maqasid al-tasyri 'in the sense of still considering the public interest oriented to the benefit and reject all munkar. Therefore, the main problem in this study is the legal sanction against the perpetrators of corruption in accordance with positive law in Indonesia in law. Islamic criminal law theory is about the distribution and operation of jinayah or jarimah and the application of sanctions. To combat corruption there are four efforts that must be done immediately, namely: first, maximize the punishment. Punishment in physical form needs to be discourse and if applicable even if necessary until the death penalty. Second, Law Enforcement Supremacy. The law must be upright and fair to be treated indiscriminately including if corruption is committed by high-ranking officials with strong power and influence. Third, System changes and improvements. The research method used is normative approach. The results concluded, corruption is generally done by people who have power in a position so that the characteristics of corruption are always associated with abuse of power, in the perspective of organized crime.

\section{Keyword : Islamic, Corupption, Islamic Criminal Law}

\section{Pendahuluan}

Korupsi merupakan suatu bentuk kejahatan yang tidak hanya diancam oleh hukum positif (Indonesia), tetapi juga keeksistensian para koruptor diancam didalam hukum Internasional dan bahkan negara-negara yang menggunakan Hukum Islam. Dalam hal ini, sasaran hukum yang hendak dituju bukan saja orang yang nyatanyata berbuat melawan hukum, melainkan juga perbuatan hukum yang mungkin akan terjadi, dan kepada alat perlengkapan 
negara untuk bertindak menurut hukum. Korupsi masalah serius, dikarenakan tindak pidana ini membahayakan pembangunan sosial sekonomi, dan juga politik, serta dapat merusak nilai-nilai demokrasi. Sulitnya penanggulangan tindak pidana korupsi terlihat dari banyak diputusbebasnya terdakwa kasus tindak pidana korupsi atau minimnya pidana yang ditanggung oleh terdakwa yang tidak sebanding dengan apa yang dilakukannya. Hal ini sangat merugikan negara dan menghambat pembangunan bangsa. Terkait Hukum Internasional, Konvensi Perserikatan Bangsa-Bangsa (PBB) Anti Korupsi 2003 (United Nations Convention Against Corruption (UNCAC), 2003) ${ }^{1}$ mendeskripsikan masalah korupsi sudah merupakan ancaman serius terhadap stabilitas, keamanan masyarakat nasional dan internasional, telah melemahkan institusi, nilai-nilai demokrasi dan keadilan, serta membahayakan pembangunan berkelanjutan maupun penegakan hukum.

Di berbagai belahan dunia, korupsi selalu mendapatkan perhatian yang lebih dibandingkan dengan tindak pidana lainnya. Fenomena ini dapat dimaklumi mengingat dampak negatif yang ditimbulkan oleh tindak pidana ini. Selama ini korupsi lebih banyak dimaklumi oleh berbagai pihak daripada memberantasnya, padahal tindak pidana korupsi adalah salah satu jenis kejahatan yang dapat menyentuh berbagai kepentingan yang menyangkut hak asasi, ideologi negara, perekonomian, keuangan negara, moral bangsa, dan sebagainya, yang merupakan perilaku jahat yang cenderung sulit ditanggulangi. Sulitnya penanggulangan tindak pidana korupsi terlihat dari banyak diputusbebasnya terdakwa yang tidak sebanding dengan apa yang dilakukannya. Hal ini sangat merugikan negara dan menghambat pembangunan bangsa. Jika ini terjadi secara terus menerus dalam waktu yang lama, dapat meniadakan rasa keadilan dan rasa kepercayaan atas hukum dan peraturan perundang-undangan oleh warga negara.

${ }^{1}$ Andi Hamzah, Pemberantasan Korupsi Melalui Hukum Pidana Nasional dan Internasional. Jakarta, 2005, PT. Raja Grafindo Persada. HIm 7
Kasus-kasus tindak pidana korupsi sulit diungkapkan karena para pelaku menggunakan peralatan yang canggih serta biasanya dilakukan oleh lebih dari satu orang dalam keadaan yang terselubung dan terorganisasi. Kejahatan ini sering disebut White Collar Crime atau kejahatan kerah putih. $^{2}$ Korupsi di Indonesia terus menunjukkan peningkatan dari tahun ke tahun. Tindak pidana korupsi sudah meluas dalam masyarakat, baik dari jumlah kasus yang terjadi dan jumlah kerugian negara, maupun dari segi kualitas tindak pidana yang dilakukan semakin sistimatis serta lingkupnya memasuki seluruh aspek kehidupan masyarakat.

Daniel Kaufman dalam laporan mengenai praktek penyuapan di peradilan di Indonesia merupakan yang tertinggi diantara negara-negara berkembang. ${ }^{3}$ Disinyalir tidak sedikit hakim di semua tingkatan peradilan yang melakukan korupsi. Akibat integritas yang rendah dan kemampuan terbatas dari hakim ini menyebabkan banyak putusan Pengadilan kasus korupsi yang tidak mencerminkan rasa keadilan masyarakat.

Di Indonesia yang terjadi adalah para pejabat-pejabat tetap bertahan dan mencoba mencari pembenaran atas tindakan-tindakannya. Sementara tindakantindakan pejabat ini jelas-jelas merupakan upaya menyalahgunakan wewenang, jabatan, dan kekuasaan. Jika substansi ${ }^{4}$ serta aparat penegak hukum bisa berlaku efektif, tentunya pencegahan dan pemberantasan terhadap para koruptor tersebut dapat direalisasikan, sehingga uang negara yang di korupsi para koruptor tersebut dapat kembali kepada negara, maka bisa jadi bangsa ini tidak terpuruk, terutama dari segi ekonomi.

2 Evi Hartanti, Tindak Pidana Korupsi. Jakarta, 2005, Sinar Grafika. hlm 3

${ }^{3}$ Daniel Kaufman, Govermance and Coruption: New Empirical Frontier For Program Design, dalam T. Mulya Lubis, "Reformasi Hukum Anti Korupsi”, Makalah disampaikan dalam Konferensi Menuju Indonesia Bebas Korupsi, Depok, 18 September 1998, hlm 8

4 (substansi dalam hal ini maksudnya adalah yang dapat diartikan sebagai sejumlah peraturan, norma dan perilaku orang-orang di dalam sistem hukum) 
Terjadinya korupsi yang bersifat politik ialah karena adanya usaha orangorang menguasai atau mendominasi kedudukan atau jabatan-jabatan tertentu yang dianggap penting dan menguntungkan. ${ }^{5}$ Usaha-usaha tersebut adalah dengan menempatkan orang-orang yang merupakan relasi terdekat yaitu famili, teman sejawat atau golongan dengan nepotisme.

Korupsi politik terjadi dalam kehidupan organisasi dan golongannya tetap menduduki posisi penting dalam suatu organisasi, dan bila usaha mempertahankan atau merebut posisi penting itu berlangsung secara tidak mempertahankan atau merebut posisi penting itu berlangsung secara tidak fair, maka tindakan dan usaha itu termasuk korupsi dalam arti politik. ${ }^{6}$ Korupsi jasa adalah berupa penggunaan tenaga kerja yang semestinya atau penggunaan tenaga kerja yang lebih daripada jam kerjanya. Masyarakat kita tidak jarang terjadinya hal sedemikian itu, lebih-lebih bila kita lihat di perusahaan-perusahaan untuk kepentingan pribadi.

Mubyarto mengutip pendapat, Theodore M. Smith, dalam tulisannya "Corruption Tradition and Change" Indonesia (Cornell University No. 11 April 1971) ${ }^{7}$ mengatakan sebagai berikut: "Secara keseluruhan korupsi di Indonesia meuncul lebih sering sebagai masalah politik daripada masalah ekonomi. Ia menyentuh keabshan (legitimasi) pemerintah di masa generasi muda, kaula elite terdidik dan pegawai pada umumnya. Korupsi mengurangi dukungan pada pemerintah dari kelompok elite di ringkat propinsi dan kabupaten." 8

Seseorang yang mempunyai wewenang tertentu dan pengaruh karena jabatannya selalu dengan mudahnya memanfaatkan tenaga kerja untuk kepentingan pribadi dan rumah tangganya, padahal semestinya pekerja tersebut harus

5 Soekanto, Soerjono, Sosiologi Suatu Pengantar, Jakarta: PT Raja Grafindo, 2002, hlm 80

${ }^{6}$ Ibid

7 Mubyarto, Ilmu Sosial dan Keadilan, Jakarta: Yayasan Agro Ekonomika, 1980, hlm. 60. 8 Ibid bekerja guna kepentingan perusahaan. Keadaan seperti ini dianggap hal yang logis oleh masyarakat karena sudah biasa dan sering terjadi. Dalam rangka menangani dan memberantas korupsi yang sudah membudaya dan sistematis, serta untuk lebih menjamin kepastian hukum, menghindari keragaman penafsiran hukum dan memberikan perlindungan terhadap hak-hak sosial ekonomi masyarakat serta perlakuan secara adil dalam memberantas korupsi, maka pemerintah memandang perlu dilakukan perubahan atas Undangundang Nomor 31 Tahun 1999 tentang Pemberantasan Tindak Pidana Korupsi. Undang-Undang Nomor 31 Tahun 1999 dirasakan belum memadai untuk Pemberantasan korupsi perlu diamanatkan dalam Ketetapan MPR RI Nomor VIII/MPR/2001 tentang Rekomendasi Arah Kebijakan Pemberantasan dan Pencegahan Korupsi, Kolusi, dan Nepotisme. Amanat ini kemudian dioperasionalkan dengan pembentukan Undang-Undang Nomor 21 Tahun 2001 tentang Perubahan Atas Undang-undang Nomor 31 Tahun 1999.

Kendala utama yang dihadapi selama penerapan Undang-Undang Nomor 31 Tahun 1999 dalam penanganan tindak pidana korupsi adalah kurangnya dukungan anggaran, sumber daya manusia yang belum memadai, hambatan-hambatan dalam penyidikan terhadap pejabat-pejabat negara, sulitnya menembus rahasia Bank, hukum acara pidana yang tidak efektif dan efisien, serta rendahnya dukungan semua pihak baik pemerintah maupun masyarakat. ${ }^{9}$ Sejarah perkembangan hukum acara pidana menunjukkan ada beberapa sistem atau teori untuk membuktikan perbuatan yang didakwakan, yaitu sistem pembuktian berdasarkan undang-undang secara positif (positief wettelijke bewijsthorie) sistem pembuktian berdasarkan keyakinan hakim saja yang logis (laconviction raissonnee) dan teori

\footnotetext{
${ }^{9}$ M.Akil Mochtar, Memberantas Korupsi Efektifitas Sistem Pembalikan Beban Pembuktian Tindak Pidana Gratifikasi, WCommunication, Jakarta, 2006, hlm. 6.
} 
pembuktian berdasarkan undang-undang secara negatif (negatif wettelijke).10

$$
\text { Hasil survey Transparency }
$$

International Indonesia (TII) pada Tahun 2004 menunjukkan, Indonesia merupakan paling korup nomor 6 dari 133 negara. ${ }^{11} \mathrm{Di}$ kawasan Asia, Bangladesh dan Myanmar lebih korup dibandingkan Indonesia. Nilai indeks persepsi korupsi (IPK) Indonesia ternyata lebih rendah daripada negaranegara tetangga, seperti Vietnam, Filipina, Malaysia, dan Singapura. ${ }^{12}$ Di dalam Hukum Nasional, aturan dan ancamannya terdapat di dalam Undang-Undang No. 31 Tahun 1999 Jo Undang-Undang No. 20 Tahun 2001 tentang pemberantasan tindak pidana korupsi, dimaksudkan agar menghilangkan keragaman penafsiran dan perlakuan adil dalam memberantas korupsi dengan ketentuan perluasan mengenai sumber perolehan alat bukti sah yang berupa "petunjuk" berupa informasi yang diucapkan, dikirim atau disimpan secara elektronik. 13 Dalam Undang-Undang tentang pemberantasan tindak pidana korupsi hanya diatur tentang korupsi material dan keuangan. ${ }^{14}$ Unsur perbuatan melawan hukum materil dalam UU No. 31 Tahun 1999 Jo UU No. 20 Tahun 2001 merupakan kontradiksi antara dianutnya asas legalitas dalam hukum pidana ataukah tidak, atau dalam kalimat yang lain apakah masih dimungkinkan hakim melakukan analogi ataukah penafsiran ekstensif. Pasal 2 ayat (1) tiada seorang pun dapat dipidana atau dikenakan tindakan, kecuali perbuatan yang dilakukan telah ditetapkan sebagai tindak pidana dalam peraturan perundangundangan yang berlaku pada saat perbuatan

${ }^{10}$ Andi Hamzah, Hukum Acara Pidana Internasional, Jakarta, Sinar Grafika, hlm. 145.

${ }^{11} \mathrm{http}$ ///www.antikorupsi.org/en/conte nt/jakarta-kota-terkorup-mahkamah-konstitusilumpuhkan-pemberantasan-korupsi,

Februari 2005

${ }^{12}$ Evi Hartanti, Tindak Pidana Korupsi. Jakarta, 2005, Sinar Grafika, hlm 2.

13 Matiman Prodjohamidjojo, Penerapan Pembuktian Terbalik Dalam Delik Korupsi (UU No. 20 Tahun 2001) Jakarta, 2009, Mandar Maju, hlm. 5.

${ }^{14}$ http://ghepheonrecht.blogspot.co.id/ 2012/04/hubungan-tindak-pidana-korupsidengan.html, Sabtu, 21 April 2012 dilakukan, selanjutnya pada ayat (3) nya dinyatakan "ketentuan sebagaimana dimaksud dalam ayat 1 tidak mengurangi tidak berlakunya hukum yang hidup dalam masyarakat yang menentukan bahwa seorang patut dipidana walaupun perbuatan tersebut tidak diatur dalam peraturan perundang-undangan.

Dalam Islam, secara teoritis kedudukan korupsi merupakan tindakan kriminal (jinayah atau jarimah) dimana bagi pelakunya diancam dengan hukuman hudud (had) dan juga hukuman ta'zir. ${ }^{15}$ Korupsi dalam dimensi pencurian (saraqah) menurut etimologinya berarti melakukan sesuatu tindakan terhadap orang lain secara tersembunyi. ${ }^{16}$ Seperti halnya korupsi yang mengambil harta dengan cara melawan hak dan tanpa sepengetahuan pemiliknya (rakyat/masyarakat). Penggelapan (korupsi) yang dilakukan oleh seorang pejabat, maka si pelaku korupsi tersebut, tidak dipotong tangannya yang dikenal dengan (Qishash), dikarenakan ia juga mempunyai saham di dalamnya, karena hasil korupsi yang ia ambil adalah uang kas negara. ${ }^{17}$ Dalam sejarah peradilan Islam, tegaknya supremasi hukum (supreme of court) didukung oleh beberapa faktor, yaitu: pertama lembaga peradilan yang bebas. Maksudnya kekuasaan kehakiman harus memiliki kebebasan dari segala macam intervensi kekuasaan eksekutif. Kedua, amanah. Maksudnya kekuasaan kehakiman merupakan amanah dari Allah SWT. ${ }^{18}$ Oleh karena itu, sebelum memutuskan, hakim selalu berlindung dan mengharap ridha Allah agar hukum yang ditetapkan memiliki rasa keadilan. Pandangan Islam tentang korupsi (penggelapan uang negara), bertolak belakang dengan ketentuan hukum pidana positif di Indonesia, yang penggelapan oleh pejabat (Pasal 415 KUHP

15 Husain Syahatah, Suap dan Korupsi Dalam Perspektif Syariah, (terjemahan oleh), Kamra As'ad Irsyad, Amzah, Jakarta, 2005,hlm. 23.

16 Muhammad Amin Suma, dkk, Pidana Islam di Indonesia, Pustaka Firdaus, 2001, hlm.111

17 HMK Barkkry, Hukum Pidana dalam Islam, AB Sitti Sjamsijah, Solo, 1958, hlm. 64.

18 BeritaIslamiMasaKini.com 
yang telah diadopsi menjadi delik korupsi oleh Undang-Undang No 20 Tahun 2001) diancam dengan pidana yang lebih berat (maksimum pidana penjara) dibanding dengan penggelapan biasa (pasal 372 KUHP) yang diancam dengan pidana maksimum 4 (empat) tahun atau denda Sembilan ratus rupiah.

Di Malaysia terdapat juga peraturan antikorupsi. Akan tetapi tidak dikenal dengan istilah korupsi melainkan dengan istilah (risywah), yang artinya korupsi. Korupsi suap (risywah) dalam pandangan hukum Islam merupakan perbuatan yang tercela dan juga merupakan dosa besar serta Allah sangat melaknatnya. ${ }^{19}$ Dengan demikian, bahwa hukuman terhadap koruptor masuk ke dalam hukuman ta'zier. Hanya dalam dimensi mencuri saja yang berupa hukuman hudud. Hukuman ta'zier adalah kejahatan yang ancaman hukumanya tidak terdapat di dalam Nash. Sehingga diserahkan kepada penguasa secara penuh. Namun dalam menjatuhkan hukuman yang tidak terdapat didalam nash harus didasarkan kepada pertimbangan akal sehat dan keyakinan hakim untuk mewujudkan maslahat dan menimbulkan rasa keadilan. Dalam hukum nasional, Malaysia juga menggunakan peraturan perundangundangan yang dikenal dengan BPR (Badan Pemberantasan rasuah). BPR dibentuk bertujuan untuk menghapuskan segala bentuk korupsi dan penyalahgunaan kekuasaan yang dilarang oleh ketentuan perundang-undangan di Malaysia. 20

Bagi para pelaku KKN di Indonesia bila memang terbukti bersalah dan dapat merugikan negara maka hukumannya haruslah setimpal dengan besarnya korupsi yang dilakukannya, sesuai amanah jabatan yang diembannya dan kadar kemudharatan yang ditimbulkannya serta kesalahan lain yang didukungnya. Dan, tentunya ia dapat dihukum berat bahkan sampai tingkat hukuman mati bila perlu dan bukan hanya sebatas hukuman potong tangan untuk menjerakan masyarakat dari praktik korupsi dan menyehatkan perekonomian

\footnotetext{
${ }^{19} \mathrm{http}: / /$ bagindams.blogspot.com/2009 /11/korupsi-dalam-perspektif-islam_23.html, 23 November 2009

20Ibid.
}

sebagaimana telah dilaksanakan di negaranegara lain seperti Cina, Jepang, dan Korea Utara. Namun masalahnya adalah para penegak dan aparat hukum serta petinggi negara harus memberi contoh sebagai clean govenrment yang bebas dari KKN sehingga mampu memberantas koruptor dan menghukum berat para koruptor tanpa pandang bulu, seperti yang dicontohkan oleh Umar bin Abdul Aziz dan Khulafaur Rasyidin sebelumnya serta maklumat Nabi SAW. yang menyatakan bahwa sekalipun putrinya sendiri mencuri niscaya akan dilaksanakan hukuman potong tangan. Mengingat Undang-Undang No. 31 Tahun 1999 Jo Undang-Undang No. 20 Tahun 2001 tentang Pemberantasan Tindak Pidana Korupsi tidak mengatur secara eksplisit mengenai sanksi terhadap pelaku tindak pidana korupsi dalam hukum Islam.

\section{Rumusan Masalah}

Yang menjadi Rumusan Masalah Pada penelitian ini adalah :

Dari uraian permasalahan latar belakang di atas masalah yang diteliti dalam penelitian ini adalah:

1. Bagaimana sanksi hukum terhadap pelaku tindak pidana korupsi berdasarkan hukum positif?

2. Bagaimana sanksi hukum terhadap pelaku tindak pidana korupsi berdasarkan hukum Islam?

\section{Metode Penelitian}

Dalam penelitian ini pendekatan yang dipakai ialah pendekatan normatif. Norma-norma yang ada dalam masyarakat bukan norma hukum saja, tetapi juga meliputi norma-norma agama, kebiasaan dan kesusilaan sehingga pendekatan normatif ini pun terlampau luas ruang lingkupnya. Terkadang norma-norma yang lain itu berjalan seiring dengan norma hukum, tetapi sering pula tidak sejalan. Fungsi penelitian yuridis normatif ditujukan untuk mengetahui dan menganalisis seperti apa dan bagaimana suatu hukum positif diimplementasikan pada suatu permasalahan tertentu. Penelitian ini penelitian kepustakaan yang ditujukan untuk memproleh bahan hukum primer yang berasal dari peraturan perundangundangan. Penelitian ini menggunakan 
metode yuridis normatif yang bersifat kualitatif. Data yang didapatkan dari hasil penelitian pustaka (bahan hukum primer). Penelitian ini akan menginventarisir normanorma atau asas-asas yang termuat dalam peraturan perundang-undangan tindak pidana korupsi dalam hukum positif di Indonesia dan dalam hukum Islam.

\section{HASIL DAN PEMBAHASAN}

Instrumen internasional merupakan suatu produk hukum tertulis dalam perangkat ketentuan ketentuan yang dihasilkan baik oleh organisasi-organisasi internasional maupun beberapa negara berupa perjanjian, konvensi, persetujuan, protokol, piagam, kovenan, akta, deklarasi, dan instrumen internasional lainnya. Tidak ada ketentuan baik dalam hukum nasional maupun hukum internasional yang mewajibkan negara untuk meratifikasi suatu konvensi atau perjanjian internasional. PBB melalui majelis umum seringkali hanya menghimbau terhadap kepada negara anggotanya untuk melakukan ratifikasi terhadap suatu konvensi maupun perjanjian internasional. ${ }^{21}$

Korupsi pada umumnya dilakukan oleh orang yang memiliki kekuasaan dalam suatu jabatan sehingga karakteristik kejahatan korupsi selalu berkaitan dengan penyalahgunaan kekuasaan, dalam perspektif kejahatan yang terorganisir, korupsi pada akhirnya dijadikan sebagai modus operandi untuk membangun diri sebagai kekuatan besar dari kejahaan terorganisir, sebagaimana dinyatakan oleh Syed Hussain Alatas bahwa korupsi adalah senjata utama kejahatan yang terorganisir untuk memantapkan kekuasaan dan kebebasan untuk berbuat. Dengan kata lain korupsi merupakan bagian atau subsistem dari kejahatan yang terorganisir. ${ }^{22}$ Korupsi tidak hanya makin luas, tetapi dilakukan secara sistematis sehingga tidak saja semata-mata merugikan keuangan negara tetapi juga telah melanggar hak-hak sosial dan ekonomi masyarakat, wajar kalau

21 Sumaryo asuryokusumo, Studi Kasus Hukum Internasional, (Jakarta : tatanusa, 2007), halaman 178

22 Syed Hussein Alatas, Sosiologi Hukum Korupsi, Jakarta, 1983, Mandar Maju, hlm. 65. korupsi digolongkan sebagai extra ordinary crime. ${ }^{23}$

Pembentuk Undang-Undang Tindak Pidana korupsi menyadari sepenuhnya bahwa tindak pidana korupsi tidak hanya dilakukan oleh orang tetapi juga oleh korporasi, melalui pengurusnya yang akhirakhir ini semakin tinggi intensitasnya dengan berbagai modus operandi. Bahkan korporasi yang dimaksud tidak hanya berbadan hukum tetapi juga yang tidak berbadan hukum. Peraturan mana, tidak dijumpai pada peraturan yang pernah berlaku sebelumnya. Sebagaimana termaktub dalam penjelasan umum bahwa "Perkembangan baru yang diatur dalam undang-undang ini adalah korporasi sebagai subjek dalam tindak pidana korupsi yang dapat dikenakan sanksi". Hal ini diatur sebelumnya dalam Undang-Undang No. 3 Tahun 1971 tentang Pemberantasan Tindak Pidana Korupsi.

Jenis korupsi yang dapat dilakukan subjek korporasi adalah seperti yang dimaksud dalam Pasal 2 ayat (1) dan (3) Undang-Undang Nomor 31 Tahun 1991 tentang pemberantasan tindak pidana korupsi yakni: "setiap orang yang secara melawan hukum melakukan perbuatan memperkaya diri sendiri atau orang lain atau suatu korporasi yang dapat merugikan keuangan negara, dan "Setiap orang yang dengan tujuan menguntungkan diri sendiri atau orang lain atau suatu korporasi, menyalahgunakan kewenangan, kesempatan atau sarana yang ada padanya karena jabatan atau kedudukan yang dapat merugikan keuangan negara atau perekonomian negara".

Subjek dalam tindak pidana korupsi yang dilakukan oleh orang, dimana sanksi pidana yang dapat dijatuhkan berupa: hukuman mati, seumur hidup, penjara dan denda. Sedangkan subjek pelaku korupsi adalah korporasi, pidana pokok yang dapat dijatuhkan hanya pidana denda. Selain pidana pokok yang dijatuhkan pada korporasi, juga pidana tambahan sebagaimana halnya pelaku korupsi adalah orang. Pemidanaan dalam tindak pidana

23 Rohim, Modus Operandi Tindak Pidana Korupsi, Jakarta, 2008, Pena Multi Media, hlm.7. 
korupsi tidak jauh berbeda dengan pengertian pemidanaan dalam tindak pidana umum karena pemberian pidana dalam arti pemidanaan sangat penting sebagai bagian politik kriminal khususnya dalam menanggulangi dan mencegah kejahatan ketentuan-ketentuan pemidanaan sebagaimana yang terdapat pada UndangUndang Nomor 31 Tahun 1999 tidaklah terlepas dari teori tentang tujuan pemidanaan serta kebijaksanaan pidana pada umumnya.

Unsur dikatakan bahwa adanya perbuatan pidana korupsi adalah didasarkan pada adanya kesalahan berupa kesengajaan (dolus, opzet, intention) yang diwarnai dengan sifat melawan hukum. Dalam bahasa Belanda asas tiada pidana tanpa kesalahan dengan istilah "Geen Straft Zonder Schuld".24Asas ini tidak dijumpai pada KUHPidana sebagaimana halnya asas legalitas, karena asas ini adalah asas yang ada dalam bentuk hukum tertulis. Hal ini apabila diabstraksikan dalam konteks grand theory berdasarkan Von Savigny, akan tergambar bahwa asas geen straft zonder schuld sebagai hukum yang hidup dan berkembang didalam masyarakat dan diakui sebagai hukum. Hal ini sesuai dengan suatu teori hukum pidana yang menyatakan bahwa hukum pidana lahir karena suatu proses rasional yang terjadi dalam masyarakat, hukum pidana merupakan suatu usaha yang rasional untuk mengkodifikasikan "kehendak masyarakat". 25

Hukum secara tegas dipisahkan dari moral dan keadilan tidak didasarkan pada penilaian baik dan buruk. ${ }^{26}$ Mengenai keadilan (justice) ini seorang Guru besar dalam bidang filosofis moral dari Glasglow University pada tahun 1750, sekaligus sebagai ahli teori hukum, "bapak ekonomi modern" yakni Adam Smith mengatakan bahwa tujuan keadilan adalah untuk

${ }^{24}$ Marpaung, Leden, Asas- Teori- Praktik Hukum Pidana, Jakarta: Sinar Grafika, 2005, hlm 26

25 Ibid

26 Lili Rasjidi dan Ira Thania Rasjidi, Pengantar Filsafat Hukum, Bandung: Mandar Maju, 2002, hlm 55 melindungi dari kerugian (the end of justice is to secure from injury). ${ }^{27}$

Asas kesalahan ini merupakan asas yang diterapkan dalam pertanggungjawaban pidana, artinya pidana hanya dijatuhkan terhadap mereka yang benar-benar telah melakukan kesalahan dalam suatu tindak pidana. Adapun mengenai pengertian kesalahan ini, Mezger mengatakan bahwa "kesalahan adalah keseluruhan syarat yang memberi dasar untuk adanya pencelaan pribadi terhadap si pembuat pidana". ${ }^{28}$

Prinsip adanya dolus dan culpa perlu dilakukan adanya bukti berdasarkan kesalahan yang dapat dipertanggungjawabkan kepada pelaku (liability on fault or negligence atau fault liability). Prinsip ini apabila dikaitkan dengan pelaku kejahatan korupsi tentunya sulit untuk dibuktikan. Oleh karenanya perlu penerapan asas hukum yang meminta pertanggungjawaban pelaku tanpa membuktikan adanya unsur kesalahan atau adanya pertanggungjawaban ketat (strict liability) tanpa harus dibuktikan ada atau ridak adanya unsur kesalahan pada si pelaku tindak pidana.

Asas strict liability adalah perlu adanya kehati-hatian terhadap keseimbangan antara kepentingan individu dengan kepentingan masyarakat, karena pertanggungjawaban pidana mengalami perubahan paradigma dari konsepsi kesalahan yang diperluas menjadi konsepsi ketiadaan kesalahan sama sekali. ${ }^{29}$ Konsep ini telah diakomodir oleh Undang-Undang No. 31 Tahun 1999 Jo Undang-Undang No. 20 Tahun 2001 tentang Pemberantasan Tindak Pidana Korupsi, yakni dianutnya asas beban pembuktian terbalik namun tidak dibarengi dengan sistem hukum acara pidana yang menganut asas sistem pembuktian stelsel negative dengan adanya bukti permulaan yang dilakukannya penyidikan dan penuntutan.

27 R.L.Meek,D.D. Raphael dan P.G. Stein, dalam Bismar Nasution, "Pengkajian Ulang Hukum Sebagai Landasan Pembangunan Ekonomi”, Forum, No.36, 2005, hlm. 5.

28 Sudarto, Hukum dan Perkembangan Masyarakat, Sinar Baru, Bandung, 1983, hlm. 30. ${ }^{29}$ Ibid 
$\begin{array}{rrr}\text { Membuktikan } & \text { bersalah tidaknya } \\ \text { seorang terdakwa haruslah melalui }\end{array}$ pemeriksaan didepan sidang pengadilan. Pembuktian ini, Hakim perlu memperhatikan kepentingan masyarakat dan kepentingan terdakwa. Kepentingan masyarakat berarti, bahwa seseorang yang telah melanggar ketentuan pidana, harus mendapat hukuman setimpal dengan kesalahannya. Sedangkan kepentingan terdakwa, berarti bahwa terdakwa harus diperlakukan secara adil sedemikian rupa, sehingga tidak ada seorang yang tidak bersalah mendapat hukuman, atau kalau seseorang memang bersalah jangan sampai mendapat hukuman yang terlalu berat dan atau jangan terlalu ringan, tetapi hukuman itu harus seimbang dengan kesalahannya. Sebab-sebab tindak pidana korupsi yang dikemukakan oleh Prof.Dr.Baharuddin Lopa, SH, yaitu: 1) yang bersumber pada kebiasaan (tradisional); 2) karena ketidakberesan manajemen; 3) karena tekanan ekonomi; 4) karena erosi mental; 4) karena gabungan beberapa faktor. ${ }^{30}$

Berdasarkan ketentuan Pasal 43 Undang-undang No. 31 Tahun 1999 tentang Pemberantasan Tindak Pidana Korupsi sebagaimana telah diubah dengan UndangUndang No. 20 Tahun 2001, badan khusus tersebut disebut Komisi Pemberantasan Korupsi yang memiiliki kewenangan melakukan koordinasi dan supervise, termasuk melakukan penyelidikan, penyidikan, dan penuntutan. Dalam Undang-Undang No. 30 Tahun 1999, terdapat jenis penjatuhan pidana yang dapat diartikan hakim terhadap terdakwa tindak pidana korupsi yaitu terhadap orang yang melakukan tindak pidana korupsi.

\section{Pidana Mati}

Tindak pidana korupsi sebagaimana dimaksud dalam ayat 1 dilakukan dalam keadaan tertentu, seperti pada waktu negara dalam keadaan bahaya sesuai undang-undang yang berlaku, pada korupsi (recidivist), atau pada waktu negara dalam keadaan krisis ekonomi dan moneter, maka pidana mati dapat dijatuhkan. Ancaman

${ }^{30}$ Djoko Prakos, Peranan Pengawasan Dalam Penangkalam Tindak Pidana Korupsi, Jakarta, 1990, Aksara Persada Indonesia. Hlm 80. pidananya adalah pidana penjara seumur hidup atau pidana penjara paling singkat 4 (empat) tahun dan paling lama 20 (dua puluh tahun) dan denda paling sedikit Rp. 200.000.000,00 (dua ratus juta rupiah) dan paling banyak Rp. 1.000.000.000,00 (satu miliar rupiah).

\section{Pidana Penjara}

a. Pidana penjara seumur hidup atau pidana penjara paling singkat 4 (empat) tahun dan paling lama 20 (dua puluh) tahun dan denda paling sedikit Rp. 200.000.000,00 (dua ratus juta rupiah) dan paling banyak Rp. 1.000.000.000,00 (satu miliar rupiah) bagi setiap orang yang secara melawan hukum melakukan perbuatan memperkaya diri sendiri atau orang lain atau suatu korporasi yang dapat merugikan keuangan Negara atau perkonomian Negara. (Pasal 2 ayat 1).

b. Pidana penjara seumur hidup atau pidana penjara paling singkat 1 (satu) tahun dan/atau denda paling sedikit Rp. 50.000.000,00 (lima puluh juta rupiah) dan paling banyak satu Rp.1.000.000.000,00 (satu miliar rupiah) bagi setiap orang yang dengan tujuan menguntungkan diri sendiri atau orang lain atau suatu korporasi, menyalahgunakan kewenangan, kesempatan, atau sarana yang ada padanya karena jabatan atau kedudukan yang dapat merugikan keuangan Negara atau perekonomian Negara (Pasal 3).

c. Pidana penjara paling singkat 3 (tiga) tahun dan paling lama 12 (dua belas) tahun dan/atau denda paling sedikit Rp.150.000.000,00 (seratus lima puluh juta rupiah) dan paling banyak $\mathrm{Rp}$. 600.000.000,00 (enam ratus juta) bagi setiap orang yang dengan sengaja mencegah, merintangi atau menggagalkan secara langsung atau tidak langsung penyidikan, penuntutan, dan pemeriksaan di siding pengadilan terhadap tersangka atau terdakwa ataupun para saksi dalam perkara korupsi. (Pasal 21). 
d. Pidana penjara paling singkat 3 (tiga) tahun dan paling lama 12 (dua belas) tahun dan/atau denda paling sedikit Rp. 150.000.000,00 (seratus lima puluh juta rupiah) dan paling banyak Rp. 600.000.000,00 (enam ratus juta rupiah) bagi setiap orang sebagaimana dimaksud dalam pasal 28, pasal 29, pasal 35, dan pasal 36.

3. Pidana Tambahan (Ganti rugi)

Perampasan barang bergerak yang berwujud atau yang tidak berwujud atau barang tidak bergerak yang digunakan untuk atau yang diperoleh dari tindak pidana korupsi, termasuk perusahaan milik terpidana dimana tindak pidana korupsi dilakukan, begitu pula dari barang yang menggantikan barang-barang tersebut. Pembayaran uang pengganti yang jumlahnya sebanyak-banyaknya sama dengan harta yang diperoleh dari tindak pidana korupsi. Ada beberapa cara terjadinya kerugian negara, ${ }^{31}$ yaitu kerugian negara yang terkait dengan berbagai transaksi: transaksi barang dan jasa, transaksi yang terkait dengan utangpiutang, dan transaksi yang terkait dengan biaya dan pendapatan. Tiga kemungkinan terjadinya kerugian negara tersebut menimbulkan beberapa kemungkinan peristiwa yang dapat merugikan keuangan negara atau perekonomian negara. 32

a. Perampasan barang bergerak yang berwujud atau yang tidak berwujud atau barang tidak bergerak yang digunakan untuk atau yang diperoleh dari tindak pidana korupsi, termasuk perusahaan milik terpidana dimana tindak pidana korupsi dilakukan, begitu pula dari barang yang menggantikan barangbarang tersebut.

b. Pembayaran uang pengganti yang jumlahnya sebanyak-banyaknya sama dengan harta yang diperoleh dari tindak pidana korupsi.

c. Penutupan seluruh atau sebagian perusahaan untuk waktu paling lama 1 (satu) tahun.

\section{Ibid \\ 32 Ibid}

d. Pencabutan seluruh atau sebagian hak-hak tertentu atau penghapusan seluruh atau sebagian keuntungan tertentu yang telah atau dapat diberikan oleh pemerintah kepada terpidana.

e. Jika terpidana tidak membayar uang pengganti paling lama dalam waktu 1 (satu) bulan sesudah putusan pengadilan yang telah memperoleh kekuatan hukum tetap maka harta bendanya dapat disita oleh jaksa dan dilelang untuk menutupi uang pengganti tersebut.

f. Dalam hal terpidana tidak mempunyai harta benda yang mencukupi untuk membayar uang pengganti maka terpidana dengan pidana penjara yang lamanya tidak memenuhi ancaman maksimum dari pidana pokoknya sesuai ketentuan undang-undang nomor 31 tahun 1999 jo undang-undang nomor 20 tahun 2001 tentang pemberantasan tindak pidana korupsi dan lamanya pidana tersebut sudah ditentukan dalam putusan pengadilan.

Dalam diskursus Hukum Pidana Islam istilah korupsi belum dikenal dan dipahami secara formal sebagai sebuah jarimah, baik di dalam Al-Qur'an maupun Hadist. $^{33}$ Ada beberapa kemungkinan yang menjadi faktor penyebabnya, diantaranya bahwa secara teknis operasional, Al-Qur'an dan hadist tidak merumuskan secara khusus tentang korupsi sehingga secara empirik jarimah ini tidak dikenal pada masa legislasi Islam awal. Korupsi sendiri dikategorikan dalam kejahatan maliyah, ${ }^{34}$ yang memiliki tiga unsur; 1) adanya tasharruf, yakni perbuatan hukum dalam bentuk mengambil, menerima, dan memberi; 2) adanya unsur pengkhianatan terhadap amanat publik yang berupa kekuasaan; 3) adanya kerugian yang ditanggung oleh masyarakat luas atau publik.

Ajaran hukum Islam yang sangat menjunjung tinggi pemeliharaan akan

\footnotetext{
${ }^{33} \mathrm{http}: / /$ www.islamcendekia.com/2014 /01/pengertian-korupsi-dalam-perspektifhukum-pidana-islam.html, 19 Januari 2014

34 Amin Muhammad Suma, dkk, Pidana Islam Di Indonesia, Pustaka Firdaus, 2001.
} 
kesucian baik lahir maupun bathin, menghendaki agar manusia (umat islam) dalam melakukan sesuatu harus sesuai fitrahnya, yakni apa yang telah dtentukan dalam al-Quran dan As Sunnah yang merupakan sumber hukum tertinggi. Pemeliharaan akan kesucian begitu ditekankan dalam hukum Islam, agar manusia (umat Islam) tidak terjerumus dalam perbuatan kehinaan atau kedhaliman baik terhadap dirinya maupun terhadap orang lain. Pelanggaran sesuatu hal dalam hukum (pidana) Islam tidak terlepas dari tujuan pokok hukum Islam (al maqashid asy-syari'ah alkhams) yang merupakan hal esensial bagi terwujudnya ketentraman hidup manusia. Adapun tujuan pokok hukum Islam tersebut adalah memelihara keselamatan agama, jiwa, akal, harta dan keturunan. ${ }^{35}$ Salah satu tujuan pokok hukum Islam ialah memelihara keselamatan (kesucian) harta. Harta merupakan rezeki dalam arti material, karena dalam bahasa agama rezeki meliputi rezeki material dan rezeki spiritual.

Pandangan dan sikap Islam terhadap korupsi sangat tegas: haram dan melarang. Banyak argumen mengapa korupsi dilarang keras dalam Islam. Selain karena secara prinsip bertentangan dengan misi sosial Islam yang ingin menegakkan keadilan sosial dan kemaslahatan semesta (iqâmat al-'adâlah alijtimâ'iyyah wa al-mashlahat al'âmmah), korupsi juga dinilai sebagai tindakan pengkhianatan dari amanat yang diterima dan pengrusakan yang serius terhadap bangunan sistem yang akuntabel. ${ }^{36}$ Oleh karena itu, baik al- Qur'an, al-Hadits maupun ijmâ' al- 'ulamâ menunjukkan pelarangannya secara tegas (sharih).

Dalam al-Qur'an, misalnya, dinyatakan: "Dan janganlah sebagian kamu memakan harta sebagian yang lain di antara kamu dengan cara batil dan (janganlah) kamu membawa (urusan) harta itu kepada hakim, supaya kamu dapat memakan sebagian daripada harta benda orang lain

35 Syahatah Husain, Suap dan Korupsi Dalam Perspektif Syariah, (terjemahan oleh), Kamra As'ad Irsyad, Amzah, Jakarta, 2005,hlm. 23.

$$
36 \text { Ibid }
$$

itu dengan (cara berbuat) dosa padahal kamu mengetahui." Dalam ayat yang lain disebutkan: "Hai orang-orang beriman, janganlah kamu saling memakan harta sesamamu dengan cara batil, kecuali dengan cara perniagaan yang berlaku dengan suka sama suka di antara kamu..." ${ }^{37}$ Sedangkan dalam al-Hadits lebih konkret lagi, dinyatakan bahwa Rasulullah SAW bersabda: "Allah melaknati penyuap dan penerima suap dalam proses hukum." Dalam redaksi lain, dinyatakan: "Rasulullah SAW melaknati penyuap, penerima suap, dan perantara dari keduanya."

Dalam sejarah, baik para sahabat Nabi, generasi sesudahnya (tabi'in), maupun para ulama periode sesudahnya, semuanya bersepakat tanpa khilaf atas keharaman korupsi, baik bagi penyuap, penerima suap maupun perantaranya. Meski ada perbedaan sedikit mengenai kriteria kecenderungan mendekati korupsi sebab implikasi yang ditimbulkannya, tetapi prinsip dasar hukum korupsi adalah haram dan dilarang. Ini artinya, secara mendasar, Islam memang sangat anti korupsi. Yang dilarang dalam Islam bukan saja perilaku korupnya, melainkan juga pada setiap pihak yang ikut terlibat dalam kerangka terjadinya tindakan korupsi itu. Bahkan kasus manipulasi dan pemerasan juga dilarang secara tegas, dan masuk dalam tindakan korupsi. Ibn Qudamah dalam al-Mughnî menjelaskan bahwa "memakan makanan haram" itu identik dengan korupsi. ${ }^{38}$ Zamakhsyari dalam tafsir al-Kasysyaf juga menyebut hal yang sama. ${ }^{39}$ Umar Ibn Khaththab berkata: "menyuap seorang hakim" adalah tindakan korupsi.

Tindak pidana korupsi sangat identik dengan penyalahgunaan jabatan yang didefinisikan sebagai perbuatan khianat dalam perspektif Islam. Karena jabatan yang telah disandang oleh seseorang adalah sebuah kepercayaan dari rakyat yang telah terlanjur menaruh

$$
{ }_{38}^{37} \text { QS A-nisa: } 29
$$

http://andrianoke.blogspot.co.id/2012/05/pan dangan-islam-pada-korupsi.html, Kamis, 01 Januari 2004 
harapan padanya. Atau jabatan yang langsung dibebankan atas nama negara yang tentunya bertujuan untuk menjalankan berbagai program yang bermuara kepada kesejahteraan rakyat. Terlebih lagi jika amanat itu menyentuh pada ranah hukum seperti pegawai pada bidang kepolisian, kejaksaan, kehakiman, dll yang berbasis kepada keadilan yang diinginkan oleh semua pihak. Amanat yang telah diemban itulah yang tentunya wajib untuk dilaksanakan sebaik-baiknya. Allah swt berfirman dalam beberapa ayat mengenai keajiban menjalankan amanat, yaitu:

"Hai orang-orang yang beriman, janganlah kamu mengkhianati Allah dan Rasul (Muhammad) dan (juga) janganlah kamu mengkhianati amanat-amanat yang dipercayakan kepadamu, sedang kamu mengetahui." (QS. al-Anfal (8) : 27)

Dalam syariah ancaman terhadap pelaku sariqah (pencurian) ditentukan dengan jelas sebagaimana yang disebutkan dalam surat Al Maidah: 38, Allah berfirman:"Laki-laki yang mencuri dan perempuan yang mencuri, maka potomglah tangan keduanya (sebagai) pembalasan bagi apa yang mereka kerjakan". Sehubungan dengan hukuman potong tangan dalam jarimah sariqah (pencurian) terdapat perbedaan pendapat apakah juga berlaku terhadap korupsi karena berdasarkan hadist Nabi SAW, yang bersabda: "Tidak dipotong tangan atas penghianatan harta (koruptor), perampok dan pencopet". 40

Korupsi dalam dimensi penipuan (al gasysy).41 Secara tegas berdasarkan sabda Rosulullah saw, Allah mengharamkan surga bagi orang-orang yang melakukan penipuan. Terlebih penipuan itu dilakukan oleh seorang pemimpin yang mempecundangi rakyatnya. "Dari $A b u$ Ya'la Ma'qal ibn Yasar berkata: "Aku mendengar Rosulullah saw. Bersabda :" seorang hamba yang dianugerahi allah jabatan kepemimpinan, lalu dia menipu rakyatnya; maka Allah mengharamkannya masuk surga." (H.R. Bukhari dan Muslim). Korupsi dalam

\footnotetext{
40 Ibid

41 Hanafi A, Azas-azas Hukum Pidana Islam, (Jakarta, Bulan Bintang, 1993), hal.69
}

dimensi khianat (penghianatan). ${ }^{42}$ Bahasa Agama tentang korupsi yang sebenarnya adalah khianat (penghianatan), khianat berkecenderungan mengabailak, menyalahgunakan, dan penyelewengan terhadap tugas, wewenang dan kepercayaan yang amanahkan kepada dirinya. Khianat adalah pengingkaran atas amanah yang dibebankan kepada dirnya atau mengirangi kewajiban-kewajiban yang seharusnya dipenuhi. ${ }^{43}$ Perilaku khianat akan menyebabkan permusuhan diantara sesama karena orang yang berkhianat selalu memutar-balikkan fakta, dan juga berakibat terjadinya destruksi baik secara moral, social maupun secara politik-ekonomi. Islam melarang keras bagi orang-orang yang beriman terhadap perbuatan khianat baik terhadapa Allah, Rasul serta terhadap sesamanya. Dalam surat Al-Anfal: 27, Allah berfirman:

"Hai orang-orang yang beriman, janganlah kamu menghianati Allah dan Rasul (Muhammad) dan (juga) janganlah kamu menghianati amanatamanat yang dipercayakan kepadamu, sedang kamu mengetahuinya".

Ulama sepakat bahwa ta'zier dapat diterapkan pada setiap maksiat pelanggaran yang tidak ada hukum haddnya. ${ }^{44}$ Adanya Ta'zier dalam hukum Islam menjamin rasa keadilan masyarakat untuk mewujudkan maslahat. Yang sifat dan bentuk hukuman ta'zir deserahkan kepada kebijaksanaan akal sehat, keyakinan dan rasa keadilan hakim yang didasarkan keadilan masyarakat. Prinsip-prinsip dalam pidana Islam ada 3 macam, yaitu: 45

a. Hukumnya hanya ditimpakan kepada orang yang berbuat jarimah atau pidana, tidak boleh orang yang tidak berbuat jahat dikenai hukuman.

b. Adanya kesengajaan. Seseorang dihukum karena kejahatan apabila ada unsur kesengajaan untuk berbuat itu, tidak ada kesengajaan berarti ada kelalaian, tersalah, atau keliru atau

42

http://alquran.babinrohis.esdm.go.id/images/8 /8_27.png

$$
\begin{aligned}
& { }^{43} \mathrm{Ibid} \\
& { }^{44} \mathrm{Ibid} \\
& { }^{45} \mathrm{Ibid}
\end{aligned}
$$


terlupa. Walaupun tersalah, atau keliru atau terlupa ada hukumanya, namun bukan hukuman karena kejahatan, melainkan untuk kemaslahatan dan bersifat mendidik.

c. Hukuman hanya dijatuhkan apabila kejahatan itu secara meyakinkan telah diperbuat.

Secara umum, korupsi dalam hukum Islam lebih ditunjukkan sebagai tindakan kriminal yang secara prinsip bertentangan dengan moral dan etika keagamaan, karena itu tidak terdapat istilah yang tegas menyatakan istilah korupsi. Dengan demikian, sanksi pidana atas tindak pidana korupsi adalah takzir, ${ }^{46}$ bentuk hukuman yang diputuskan berdasarkan kebijakan lembaga yang berwenang dalam suatu masyarakat. Hadis-hadis yang disebutkan di atas pun tidak secara tegas menyebutkan bentuk sanksi yang dapat dijatuhkan kepada pelaku korupsi. Nash-nash tersebut hanya menunjukkan adanya keharaman atas perbuatan korupsi yang meliputi suap menyuap, penyalahgunaan jabatan atau kewenangan, dsb. Sehingga ayat dan hadis di atas hanya menunjukkan kepada sanksi akhirat. Hal ini mengingat bahwa syariat Islam memang multidimensi, yaitu meliputi dunia dan akhirat. Untuk menjerat para koruptor agar dapat merasakan pedihnya sanksi pidana, maka dapat dijatuhi sanksi takzir sebagai alternatif ketika sebuah kasus pidana tidak ditentukan secara tegas hukumannya oleh nash. Jika dilihat lebih lanjut,tindak pidana korupsi agak mirip dengan pencurian. Hal ini jika kita melihat bahwa pelaku mengambil dan memperkaya diri sendiri dengan harta yang bukan haknya. Namun, delik pencurian sebagai jarimah hudud, tidak bisa dianalogikan dengan suatu tindak pidana yang sejenis. Karena tidak ada qiyas dalam masalah hudud. Karena hudud merupakan sebuah bentuk hukuman yang telah baku mengenai konsepnya dalam al-Qur'an. Kemudian terdapat perbedaan antara delik korupsi dan pencurian. Dalam tindak pidana pencurian, harta sebagai objek curian berada di luar kekuasaan pelaku dan tidak ada hubungan dengan kedudukan pelaku.

46 Munawar Fuad Noeh,Islam dan Gerakan Moral Anti Korupsi,hal 90
Sedangkan pada delik korupsi, harta sebagai objek dari perbuatan pidana, berada di bawah kekuasaannya dan ada kaitannya dengan kedudukan pelaku. Bahkan, mungkin saja terdapat hak miliknya dalam harta yang dikorupsinya.

Al-Quran diturunkan oleh Allah kepada umat manusia guna dijadikan sabagai pedoman hidup dalam mengemban tugas/amanah sebagai khalifah Allah di bumi. Al-Quran sebagai kitab suci yang menyempurnakan kitab-kitab suci terdahulu, adalah shalih li kulli zaman wa makan (tepat untuk setiap zaman dan tempat), dan rahmatan lil 'alamin (rahmat bagi seluruh alam). ${ }^{47}$ Dan Nabi Muhammad SAW, dengan Sunnahnya merupakan uswatun hasanah dalam segala perkataan, perbuatan dan perilakunya. Keduanya merupakan sumber pokok ajaran Islam yang digunakan oleh seluruh umat Islam, sebagai hudan li al-nas.

Ulama Ushul Fiqh membagi ayatayat hukum dalam al-Quran kepada dua bentuk:48 yaitu (a) hukum-hukum yang bersifat rinci (juz'iy), sehingga ayat-ayat tersebut oleh mereka disebut sebagai hukum ta'abbudi (yang tidak dapat dimasuki atau diintervensi akal), dan hukum-hukum yang bersifat global (kulli) yang merupakan sebagian besar kandungan ayat-ayat hukum dalam al-Quran, dalam hal ini Sunnah berperan sebagai penjelas, pengkhusus dan pembatas dari ayat-ayat tersebut. ${ }^{49}$ Hukum Islam dalam suatu masyarakat manapun dan dimanapun, adalah bertujuan untuk mengendalikan, mengatur, dan sebagai alat kontrol masyarakat, ia adalah sebuah sistem yang ditegakkan, terutama untuk melindungi individu maupun hak-hak masyarakat ${ }^{50}$.

\section{Penutup \\ Kesimpulan}

Tindak pidana korupsi, menjadi salah satu permasalahan bangsa Indonesia. Karena tindak pidana ini, Indonesia telah
${ }^{47}$ Ibid
48 Ibid
49 Ibid
50 Saleh, Wantjik.Tindak Pidana Korupsi di Indonesia. Ghalia Indonesia, Jakarta, 1978, hlm 25 . 
banyak menelan kerugian karena pihakpihak yang sangat tidak amanah dalam mengemban jabatan dan kekuasaan. Dalam mengatasi tindak pidana korupsi yang telah menggurita dan menginfeksi seluruh rongga kehidupan bangsa, para wakil rakyat dan intelektual negeri ini mencoba menciptakan sebuah instrumen hukum yang diwujudkan dengan Undang-Undang No 39 Tahun 1999 sebagaimana telah diubah dengan UndangUndang No 20 Tahun 2001 Tentang Tindak Pidana Korupsi. Tindak Pidana Korupsi dalam hukum Islam lebih ditunjukkan sebagai tindakan kriminal yang secara prinsip bertentangan dengan moral dan etika keagamaan, karena itu tidak terdapat istilah yang tegas menyatakan istilah korupsi. Tindakan korupsi jelas merupakan perlawanan terhadap tujuan kelima; hifzh al-mal. Apabila dalam kepustakaan hukum Islam, contoh populer perbuatan melawan tujuan hifdh al-mal ini adalah kejahatan mencuri (al-sariqah) milik perorangan, maka korupsi sebagai kejahatan mencuri harta milik bangsa dan negara lebih layak lagi untuk dicatat sebagai pelanggaran yang sangat serius terhadap prinsip hifzh al-mal. Korupsi bukanlah pencurian biasa dengan dampaknya yang bersifat personalindividual, melainkan ia merupakan bentuk pencurian besar dengan dampaknya yang bersifat massal-komunal. Bahkan ketika korupsi sudah merajalela dalam suatu negara sehingga negara itu nyaris bangkrut dan tak berdaya dalam menyejahterakan kehidupan rakyatnya, tidak mampu menyelamatkan mereka dari ancaman gizi buruk dan busung lapar yang mendera, maka korupsi lebih jauh dapat dianggap sebagai ancaman bagi tujuan syari'at dalam melindungi jiwa manusia (hifzh al-nafs). Dalam perumusannya hukum Islam mempunyai tujuan utama untuk mewujudkan dan memelihara lima sasaran pokok (al-maqashid al-syar'iyyah), yaitu: agama, jiwa, akal, kehormatan atau keturunan, dan harta. Kelima hal pokok tadi wajib diwujudkan dan dipelihara demi terwujudnya kemaslahatan manusia, yang dengan itu tercapailah apa yang disebut, kebaikan di dunia dan kebaikan di akhirat.Dengan demikian, segala perbuatan atau tindakan yang bisa mengancam keselamatan salah satu dari kelima hal pokok teersebut, maka patut dianggap sebagai tindak kejahatan (delik) yang dilarang, dan untuk melindungi dan memelihara kelima hal pokok tersebut dan kemaslahatan manusia pada umumnya, Islam menetapkan dan menegaskan sejumlah peraturan-peraturan, baik berupa perintah maupun larangan, dan dalam hal tertentu aturan-aturan tersebut disertai dengan ancaman hukuman atau sanksi duniawi dan/atau ukhrawi, jika peraturan tersebut dilanggar.

\section{DAFTAR PUSTAKA}

Hamzah, Andi. Pemberantasan Korupsi Melalui Hukum Pidana Nasional dan Internasional. Jakarta: PT. Raja Grafindo Persada, 2005.

Prakoso, Djoko. Peranan Pengawasan Dalam Penangkalam Tindak Pidana Korupsi, Jakarta: Aksara Persada Indonesia. 1990.

Hartanti, Evi. Tindak Pidana Korupsi. Jakarta: Sinar Grafika. 2005.

HMK Barkkry, Hukum Pidana dalam Islam, Solo: AB Sitti Sjamsijah. 1958.

Prodjohamidjojo, Matiman. Penerapan Pembuktian Terbalik dalam Delik Korupsi, Jakarta: Mandar Maju. 2009.

Rohim. Modus Operandi Tindak Pidana Korupsi. Jakarta:Pena Multi Media. 2008.

Alatas, Syed Hussein. Sosiologi Hukum Korupsi, Jakarta: Mandar Maju. 1983.

Lamintang, PAF dan Samosir, Djisman. Hukum Pidana Indonesia. Bandung, Penerbit Sinar Baru, 1985.

Munawar Fuad Noeh,Islam dan Gerakan Moral Anti Korupsi, Jakarta: Zikhru'l Hakim,1997

Fauziah Raad, "Pemberantasan Korupsi Bermula dan Berakhir Berdasar Legalitas:

http//www.transparansi.or.id, Agustus, 2006.

Hariyanto Kurniawan, "Sistem Pembuktian Terbalik dapat Dijadikan UU" http://www.okezone.com.

Komisi Hukum Nasional, "Pembuktian Terbalik dalam RUU KUHP”, 
http://www.komisihukum.go.id,Apr il, 2007.

http:wikipedia.org/wiki/gratifikasi,Jakarta, 27 september 2012.

Nasution, Bismar, Mencegah Korupsi dengan Keterbukaan, Forum No. 36, 2005.

Arief, Barda Nawawi, Pokok-Pokok Pikiran Kebijakan Pembaharuan UndangUndang

Pemberantasan Tindak Pidana Korupsi, Makalah Seminar di Unsoed, Purwokerto, 1991.

Undang-Undang Nomor 31 Tahun 1999 jo Undang-undang Nomor 20 Tahun 2001 tentang Pemberantasan Tindak Pidana Korupsi.

Undang-Undang Nomor 30 Tahun 2002 tentang Komisi Pemberantasan Korupsi

Undang-Undang Nomor 8 Tahun 1981 tentang Kitab Undang-Undang Hukum Acara Pidana. 